\title{
Islamic Feminism: Muslim Voices versus Instrumented Voices
}

\author{
By/ Abdallah Mahmoud Shafiq
}

PhD student At Helwan University 


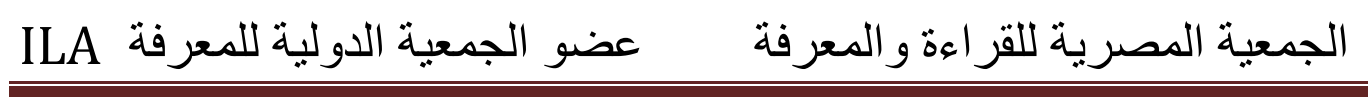




\section{Islamic Feminism: Muslim Voices versus Instrumented}

\section{Voices}

For many people in the West, Islam means terrorism. A number of horrendous terrorist acts carried out in western countries by people who claim the Muslim faith has understandably prompted westerners to associate Islam with terrorism and has given rise to the idea that they are living in an "age of terror," one in which Muslim threats are ever present. The west is largely influenced by deeprooted assumptions that Islam is a monolithic religion controlling all aspects of its adherents' lives. They dismiss the idea of Islamic feminism because they think that Islam is a religion of oppression. Islam and feminism cannot meet together and hence the controversy around the term "Islamic feminism," its usefulness, and even its very existence has divided many Muslim feminists and scholars into two camps. Valentine Moghadam, an Islamic feminist activist, sees the camps as split between those who defend the importance of Islamic feminism as a movement and theory and those who oppose its legitimacy, value and use and deny its existence (Moghadam, 22).

As for the opponents of Islamic feminism, they argue that Islamic feminism is an oxymoron because Islam and feminism are in essence incompatible with each other. Therefore, Islamic feminism is criticized for jeopardizing reformist movements with socialist and Marxist bends since it is seen as an example of "bargain (ing) with patriarchy" (Kandiyoti 317). It does not offer a solid ground for a total social reform or a social, political and ideological breakthrough. This second camp, which includes Margot Badran, Afsaneh Najamabadi, NayerehTohidi and Miriam Cooke, argues that Islamic feminism is a middle-ground between secular and religious feminisms, (absolutism, salavis and fundamentalism) an agent in geographies where modernization is ongoing, and is an alternative discourse to the orientalist and colonialist viewpoints of western 
feminism towards Muslim woman and women living in the middle East and North Africa in general (Hossieni 18). Badran argues:

I see Islamic feminism at the center of a transformation within Islam struggling to make head way. I call this a transformation rather than a Reformation. The Islamic transformation is not about the reforming of patriarchal claims and practices that were insinuated into Islam; it is about the transforming of what has passed as 'Islam' through a real of Islam with the Qur'nic message of gender equality and social justice. ... [and thus this] transformation is about restoring the deep Qur'anic message to the surface of awareness and articulation. (11)

Badran asserts that Islamic feminism emerged as a new discourse of women, gender and equality in Islam. It was born of the intimate combination of women's existential knowledge and their rereadings of the Qur'an and other religious texts. In the last years of the 20th century, Islamic feminism burst upon the scene of the global umma (Muslim community). Badran explains how Political Islam as a movement (Islamism) was well underway at the time and was bent on re-imposing, in the name of religion, patriarchal thinking and practices. At the same time, many women had been primed by education, training and an intensified gender consciousness to reread Islamic religious texts for themselves and stand by their positions. Islamic feminism is the first theology-driven feminist discourse to have been broadly received by ordinary and privileged women alike (Badran22).

It is worth saying that Miriam Cooke coined the term "Muslim woman" which is highly significant and reflecting of the oriental point of view fuelled after 9/11 in order to understand the opposition against Islamic feminism. Using this term (Muslim woman) creates an image of a monolithic Muslim-woman or identity that assumes that being a Muslim woman is in essence something oppressing, and 
Muslim women are victims of Islam's patriarchal essence and inevitably are oppressed (Cooke 142). Hence, Islamic feminism in Cooke's point of view is related to her analysis of this image:

Whenever Muslim women offer a critique of some aspect of Islamic history or hermeneutics, they do so with and/or on behalf of all Muslim women and their right to enjoy with men full participation in a just community, I call them Islamic feminists. This label is not rigid; rather it describes an attitude and intention to seek justice and citizenship for Muslim women (Cooke 91).

From this perspective, Cooke assures that all women will benefit from the critique of (traditional) Islamic history and hermeneutics because it will provide a positive change in the efforts to create a just community for Muslims. Cooke asserts that multiple and different identities of Muslimhood in terms of ethnicity, politics and socially can come together with Islamic feminism in order to claim "simultaneous and some contradictory allegiance even as they resist globalization, local nationalisms, Islamization, and the pervasive patriarchal system" (Cooke 108). Therefore, Cooke, MirHosseini and Badran agree on that Islamic feminism transcends the limits "of both the inside and outside dimensions of a woman's movement. By exceeding those limits, Cooke stands for how a subalternized group can assume its essentialized representations and use them strategically against those who have ascribed them" (Cooke 101). Therefore, Islamic feminists challenge the traditional, orthodox reading of the religion of Islam for a more just sociopolitical order for women and men alike (Cooke 98).

In the last decade and within such a context of representation of Islam and Muslim women in the west, "a number of novels have been written in English by women authors and published in western 
countries. These novels tell a different story about Islam and about Muslim women" (Ameri 3).

As far as the selected writers are concerned, many studies have already examined and expounded the characteristics of Islamic feminism. Yet no studies have attempted to place the anti- and proIslamic feminist writers vis-a-vis. The selected works "challenge" and impugn the contradicting attitudes and misconceptions of the anti-Islamic feminists as well as try to produce a new space for understanding the issues of Muslim women in the light of Islamic conceptions to destabilize the allegations of anti-feminist writers. Therefore, the present research is an attempt to place the anti and the pro-Islamic feminist writers vis-a-vis.

The four chosen writers, Ayan Hirsi Ali, and Nisrin Taslima, Randa Abdel-Fattah, Leila Aboulela, represent two contradicting camps of Islamic feminism. They also represent different Muslim countries: Egypt, Bangladesh, Indonesia, Somalia, and the Sudan. They have contributed to Islamic feminism by using their creative writings as a vehicle to express their ideas and opinions about Islam and women. These writings have had a great influence on their readers and the feminist movement as a whole and on Islamic feminism in particular.

Nisrin Taslima and Ayan Hirsi Ali represent the anti-Islamic feminism camp. Nisrin Taslima was born in Bangladesh to a Muslim family but was brought up in a secular environment. She got her degree in Medicine and worked in hospitals. She started writing in magazines in 1980s and 1990s. She criticized Islamic oppression of women. She received some awards for her works and her novels and books were translated and published in many Indian and European languages. She published her novel Lajja in 1993- She claims that religion drivers people to madness, at which point they do not hesitate to abandon even basic humanity: Lajja means shame. 
As for Ayan Hirsi Ali, she is a native of Somalia and was a member of the parliament of the Netherlands until 2006. She is the author of Infidel (2006). She has come to be widely regarded as the most influential spokesperson for Muslim women worldwide (Hussien I). Her novel, Infidel, is an autobiography of Hirsi Ali. She states that Muslim women are oppressed became Islam is like a mental cage. "At first, when you open the door, the caged bird stays inside: it is frightened. It has internalized its imprisonment. It takes time for the bird to escape, even after someone else has opened the doors to the cage" (Ali 286).

The clash between Islam and the Enlightenment remains her focus. She regards Islam as the main reason for women's oppression and backwardness. She calls for adopting the values of the west. Hisri portrays how the women are powerless in the Muslim societies. She says that it was even harder for Asha as her husband, Hirsi's Ali father, finally left her after so many quarrels they had. She was alone in a foreign country with three little kids and her old mother. The time for Asha was very hard and she did not handle the situation wisely:

She was tyrannical, unreasonable; she screamed a life time of frustration in our faces. I know it was not hatred for as but because she was so unhappy, abandoned in a foreign country .... With three children to guide and no man to act as her anchor (67).

Hirsi Ali states that other Somali women would have worked to survive and fulfill the need of her kids. More on that matter, on page 67 Hirsi Ali also states: .. .but my mother, having absorbed the Arab attitude that pious women should not work outside her home, felt that this (working outside) would not be proper. It never occurred to her to go out and create a new life for herself, although she cannot have been older than thirty-five or forty when my father left. Instead, 
she remained completely dependent. She nursed grievances; she was resentful; she was often violent; and she was always depressed. (Hirsi Ali, p. 67)This shows how the construction is rooted deeply and affects the women severely until she feels powerless when there is no man for her to anchor herself. The idea that men are more powerful than them makes the women neglect their true capability to survive. As described by Hirsi Ali, her mother was actually still in the productive age and would have been able to work if she wanted to. Instead, she chose to sink herself deep in the idea that she is nothing without her husband. The idea that men are more superior than women is successfully planted, in this Hirsi pursues to describe Islam as a fundamentally cruel, backward and irrational. In other words, she acts or performs the of Islamization of wickedness; in her novel, which suggests how the author, a Muslim woman, hates Islam (Keshavaraz 119).

Hirsh Ali never makes any clear statement that shows how Islam should not be blamed and instead people should take a deeper look at the tradition and cultural aspects. She manages to state the facts how female genital predates Islam and not all Muslims do this. If she actually really intends to see the case objectively, then she should have put a bold statement regarding the issue to avoid any misinterpretation regarding the case. Not to mention her statement that claims Imams never discourage the practice. Without her giving a deeper analysis about Islam stance in female genital mutilation, the readers can be swayed by the words 'Imams never discourage the practice In depicting women's obedience in Islam. The distortion of the facts about Islam in Infidel appears in different forms. Sometimes, Hirsi Ali gives information that is simply inaccurate. At other times, she presents her own understanding of a religious point as a final definition and interpretation of that point At times it is a combination of these two. As an example of inaccurate information, for example' describes Muslim prayer. She describes it as an 


\section{الجمعية المصرية للقر اعة والمعرفة عضو الجمعية الدولية للمعرفة}

arduous, unbearably long ritual, calling it 'the long ritual of submission to God'.

All of these claims can be challenged based on the Quranic verses, historical information or even common sense; however, more important to the arguments of my thesis is that these assertions suggest a hate relation rather than a love relation on the part of Hirsi Ali, the Muslim or the former Muslim author, with Islam, a relation that the reader might extend to all Muslim women.

NisrinTaslima like Hirsi Ali gives a negative image of the Muslim woman in a big Islamic fundamentalist country in the Islamic world. Taslima finds religion as the sole cause for all suffering of women. Religion and patriarchy have denied the fundamental rights to women and has been responsible for creating the gender bias among men and women. Religion and gender issues hold the key in her novel Lajja. Taslima fights against Islamic fundamentalism. According to Taslima religion which has been used for the comforts of men since its creation is used to oppress women women's rights. (Srikanth. S P.75)

Through the novel, Taslima conveys that men use religion as a shelter to do all kinds of atrocities on women. She wants to show how the young Muslims during the communal violence misbehave with the women of other religion. She asks what right do these young Muslims have to torture women on the banner of religion? Does religion ask or preach men to brutal with women? (Srikanth. S 76)

Taslima belongs to the feminist writers who regard Islam as inherently gender oppressive, castigates it and prefers like Hirsi Ali the western, secular feminist framework to ameliorate women's conditions. (Mahmudul 168) She asserts that Islam was born out of ignorance. It is still shamelessly showing its barbaric behavior all over the world. Blind believes of Islam have no intention to stop 
persecuting people, humiliating humanity, stoning women, banning conscience, burning books in the name of protecting their God and prophet (No country for women 16).She continues to criticize Islam:

We hear distributing news every day. Women are stoned to death for being in love, writers or artists or human rights activists are lashed, slaughtered, imprisoned, and hanged for criticizing Islam.

I wonder why Muslims are not a shamed of Islam. How many countries do they need to know that Islam is not a religion of peace, it is just an anti-human rights, anti-free speech, anti-democracy religion which was created by an Arab camel driver for his own interest. (No country for women 20).

The most noticeable fact is that Nisrin portray Islam as the black cobra and recommended sweeping it with a broom. Nisrin uses a stereotypical representation of Muslims, claiming that illiterate and uneducated people who had no scientific knowledge would believe in religion (Hassan 173). According to Taslima, believers in Islam don't have brain. When she criticizes Islam, many of her statements are charged with emotions, outright impropriety and offensiveness (Hassan 173).

Randa Abdel Fattah and Leila Aboulela represent the other camp which uses Muslim feminism as a tool to confront and disperses the adopted concepts and conception of anti-Islamic feminism. The second Islamic feminist writer is Randa Abdel Fattah. A Muslim of Palestinian and Egyptian parentage, Abdel Fattah was born in Sydney, Australia in 1979. She wrote Does My Head look Big in This? (2005), Ten Things I Hate about Me (2006), Where the Streets Had a Name (2008) Noah (2010), and No Sex in the City (2015) (Wikipedia). In her novel Does My Head Look Big in This? She wants to denude the common misconceptions about Muslims and allow the readers to enter the world of average Muslim women and see beyond the headlines and stereotypes--to realize that Muslim 
women are experiencing the same dramas and challenges of life as their non-Muslim peers. Abdel-Fattah attempts to present the importance of being religious while creating strong ties with nonMuslim community (AbdulMajid 59). Amal, who is the only child to religious parents who take care of performing Islamic practices, is a typical teenage girl who argues with her mother, gets annoyed at her father, and cares about her appearances. Amal is also described as a smart, confident and ambitious girl. She is, then, Abdel-Fattah's attempt to convey a different image of a young religious Muslim woman. This image stands against the stereotypical portrait of submissive and subjugated qualities of Muslim women (Abdulmajid 60). Abdel-Fattah chooses a positive representation of a Muslim woman who is not a victim of any form of oppression.

The four proponent of Islamic feminism is Leila Aboulela. She is a Sudanese-born writer whose work, written in English, has received critical acclaim and a high profile for its distinctive exploration of identity migration and Islamic spirituality. She highlights the challenges facing Muslims and portrays characters who struggle to make choices based on Muslim ethos. In her novel The Kindness of Enemies (2015) she tackles the themes of identity, jihad and Sufism. To conclude, Islamic feminists want to convey a new trend of feminism that takes Islamic teachings as a base to counter the misconceptions and wrong attitudes of western stereotypes. They assert that Islam and feminism are not mutually exclusive. 


\section{Works Cited}

\section{Primary Sources:}

Abdal-fattah,Raanda. Does my head look big in this? Pan

Macmillan Australia Pty Ltd St Martins Tower, 31 Market Street, Sydney2007.

Abouela,Leila. The Kindness of Enemies. Grove Press 2016.

Ali, Ayaan Hirsi .Infidel. New York: Free Press, 2007.

Taslima, Nasrin. Lajja: Shame Penguin 2003.

\section{Secondary Sources:}

Abugideiri, Hibba. "Hagar: A Historical Model for 'Gender Jihad'."

In Daughters of Abraham: Feminist Thought in Judaism,

Christianity and Islam, edited by Yvonne Y. Haddad and John L.

Esposito, 81-107. Gainesville, FL: University Press of Florida, 2001.

Abu-Lughod, Lila. "Do Muslim Women Really Need Saving?

Anthropological Reflections on Cultural Relativism and Its

Others." American Anthropologist 104, no. 3 (September 2002):

783-790.

. "Crimes of Honor and the Construction of Gender in Arab

Societies." In Feminism and Islam: Legal and Literary

Perspectives, edited by Mai Yamani, 141-194. Reading: Ithaca

Press, 1996.

Islamic Law and the Challenges of Modernity, edited by Yvonne

Y. Haddad and Barbara Stowasser, 103-211. Walnut Creek, CA:

Altamira Press, 2004.

- "Post-Colonial Feminism and the Veil: Thinking the

Difference." Feminist Review 43 (1993): 26-37.

Afkhami, Mahnaz. "Claiming Our Rights: A Manual for Women's

Human Rights Education in Muslim Societies." In Muslim

Women and the Politics of Participation: Implementing the 
Beijing Platform, edited by Mahnaz Afkhami and Erika Friedl, 109-120. Syracuse: Syracuse University Press, 1997. ."Rethinking Women's Issues in Muslim Communities." In

Taking Back Islam: American Muslims Reclaim their Faith, edited by Michael Wolfe and the producers of Beliefnet, 91-98. N.p.: St. Martin's Press, 2002.

Ali, Shaheen S. Gender and Human Rights in Islam and International Law: Equal Before Allah, Unequal Before Man? The Hague: Kluwer Law International, 2000.

Alireza, Marianne. At the Drop of a Veil. Boston: Houghton Mifflin Co., 1971.

Altorki, Soraya. "Getting God's Ear: Women, Islam and Healing in Saudi Arabia and the Gulf." The Middle East Journal 55, no. 1 (winter 2001): 160-163.

Altorki, Soraya and Camillia Fawzi el-Solh, eds. Arab Women in the Field: Studying Your Own Society. Syracuse: Syracuse University Press, 1988.

Al-Rasheed, Madawi. "The Meaning of Marriage and Status in Exile: The Experience of Iraqi Women." Journal of Refugee Studies 6 (1993): 89-104.

Ameri, Ameri. "Veiled experiences: re-writing women's identities and experiences in contemporary Muslim fiction in

English.’Murdoch University, Terhan, 2012.

Anwar, Ghazala. "Muslim Feminist Discourses." In Feminist

Theology in Different Contexts, edited by Elisabeth S. Fiorenza and Shawn Copeland, 55-61. London: SCM Press, 1996. Arimpi, D. A. "Reading the writings of contemporary Indonesian Muslim women writers: representation identity and religion of Muslim women in Indonesian fictions. University of new south wales, Australia 2006.

Assad, Soraya. "Current Status of Literature on Muslim Women: A Case Study." Journal, Institute of Muslim Minority Affairs 10, no. 1 (1989): 171-198. 
Badran, Margot. "Feminists, Islam and the Nation: Gender and the Making of Modern Egypt." Princeton: Princeton University

Press, 1995.

-. "Understanding Islam, Islamism, and Islamic Feminism."

Journal of Women's History 13, no. 1 (spring 2001): 47-54.

Bannerji, Himani, Shahrzad Mojab, and Judith Whitehead. Of

Property and Propriety: The Role of Gender and Class in

Imperialism and Nationalism. Toronto: University of Toronto

Press, 2001.

Barlas, Asma. "Believing Women in Islam: Unreading Patriarchal Interpretations of the Quran". Austin: University of Texas Press, 2002.

Bewley, Aisha A. Islam: The Empowering of Women. London: TaHa, 1999.

Cooke,Miriam. "Women Claim Islam: Creating Islamic Islam through literature." New York Routledge 2001.

El Saadawi, Nawal. "Toward Women's Power, Nationally and Internationally." In Speaking of Faith: Cross-Cultural Perspectives on Women and Social Change, edited by D. L. Eck and D. Jain, 247-254. London: Women's Press, 1986. "Women, Religion, and Culture." In Bridging the Cultural

Gap: A European-Arab/Muslim Conference, Louisiana-

Denmark, edited by Niels Barfoed and Anders Jerichow, 107-

118. Copenhagen: Danish PEN, 1995.

Gole, Nilufer. The Forbidden Modern: Civilization and Veiling. Ann Arbor: University of Michigan Press, 1996. . "The Freedom of Seduction for Muslim Women." New Perspectives Quarterly 15, no. 3 (1998): 43-51. . Why I am a Muslim: An American Odyssey. London:

Element Books, 2004.

Hassan, Riffat. "Challenging the Stereotypes of Fundamentalism: An Islamic Feminist Perspective.” The Muslim World 91, no.1/2 (spring 2001): 55-70. 
Hussien, Shakira. "Gender discrimination, multiculturalism and Islam: Ayaan Hirsi Ali and the question of women." Uoniversity of Melbourne.shussein@unimelb.edu.au

Interview with Omaima Abu Bakr, available at http://www.musafira.de/islamissenschaet/interview-withomaima-abou-bakr-on-science-islamic-and-history/

Kahf, Mohja. E-mails From Shehrazad. Gainesville: University Press of Florida, 2003.

Kandiyoti, Deniz. "Beyond Beijing: Obstacles and Prospects for the Middle East." In Muslim Women and the Politics of

Participation: Implementing the Beijing Platform, edited by Mahnaz Afkhami and Erika Friedl, 3-10. Syracuse: Syracuse University Press, 1997.

. "Contemporary Feminist Scholarship and Middle East Studies." Gendering the Middle East: Emerging Perspectives, edited by Deniz Kandiyoti, 1-27. London: Tauris, 1996.

- "Islam and Feminism: A Misplaced Polarity." WAF Journal, no. 8 (1996): 10-13.

Karam, Azza M. "Muslim Feminists in Western Academia:

Questions of Power, Matters of Necessity." In Islam in the Era of Globalization: Muslim Attitudes towards Modernity and Identity, edited by Johan H. Meuleman, 171-187. London:

Routledge/Curzon, 2002.

Mernissi, Fatima. Beyond the Veil: Male-Female Dynamics in Modern Muslim Society. Bloomington, IN: Indiana University Press, 1990.

- Dreams of Trespass. Reading, MA: Addison-Wesley Pub. Co., 1994.

. The Forgotten Queens of Islam. Minneapolis: University of Minnesota Press, 1997.

- "Muslim Women and Fundamentalism." In Arab Women: Between Defiance and Restraint, edited by Suha Sabbagh, 162168. New York: Olive Branch Press, 1996. 
- The Veil and the Male Elite: A Feminist Interpretation of Women's Rights in Islam. Reading, MA: Addison-Wesley Publishing Co., 1991.

- Women's Rebellion and Islamic Memory. London: Zed, 1996. Milani, Farzaneh. Veils and Words: The Emerging Voice of Iranian Women Writers. Syracuse: Syracuse University Press, 1992.

Mir-Hosseini, Ziba. "Debating Gender with Ulema in Qom." International Institute for the Study of Islam in the Modern World (ISIM) Newsletter 5 (2000): 21.

- Islam and Gender: The Religious Debate in Contemporary Iran. Princeton: Princeton University Press, 1999.

_. "Islam, Women and Civil Rights: The Religious Debate in the Iran of the 1990s." In Women, Religion and Culture in Iran, edited by Sarah Ansari and Vanessa Martin, 169-188.

Richmond: Routledge/Curzon, 2002.

. Marriage on Trial: A Study of Islamic Family Life. London:

I. B. Tauris, 2000.

. "Religious Modernists and the 'Woman Question'." In

Twenty Years of Islamic Revolution: Political and Social

Transition in Iran since 1979, edited by Eric Hooglund, 74-95.

Syracuse: Syracuse University Press, 2002.

- "The Rise and Fall of Fa'ezeh Hashemi: Women in Iranian Elections." Middle East Report, no. 218 (2001): 8-11.

. "Stretching the Limits: A Feminist Reading of the Sharia in

Post- Khomeini Iran." In Feminism and Islam: Legal and

Literary Perspectives, edited by Mai Yamani, 285-319. Reading:

Ithaca Press, 1996.

"Women and Politics in Post-Khomeini Iran: Divorce,

Veiling and Emerging Voices." In Women and Politics in the

Third World, edited by Haleh Afshar, 142-170. London:

Routledge, 1996. Mirza, Heidi Safia. Young, Female and Black.

London: Routledge, 1992. 
Moghadam, Valentine M. "Engendering Citizenship, Feminizing

Civil Society: The Case of the Middle East and North Africa."

Women and Politics 25, no. 1/2 (spring 2004): 63.

—. "Feminism and Islamic Fundamentalism: A Secularist

Interpretation." Journal of Women's History 13, no. 1 (spring 2001): 42-46.

- Gender and National Identity: Women and Politics in

Muslim Society. Karachi: Oxford University Press, 1994.

-. "Islamic Feminism and Its Discontents: Toward a

Resolution of the Debate." Signs: Journal of Women in Culture

and Society 27, no. 4 (summer 2002): 1135-1171.

. "Patriarchy in Transition: Women and the Changing Family

in the Middle East." Journal of Comparative Family Studies 35,

no. 2 (spring 2004): 137-162.

- ed. Identity Politics and Women: Cultural Reassertions and

Feminisms in International Perspective. Boulder: Westview,

1994.

Moghissi, Haideh. Feminism and Islamic Fundamentalism: The

Limits of Postmodern Analysis. London: Zed Books, 1999.

Mohamad, Maznah. "Poststructuralism, Power and Third World

Feminism." Kajian Malaysia 12, no. 1-2 (1994): 119-143.

Mojab, Shahrzad. "'Muslim' Women and 'Western' Feminists: the

debate on Particulars and Universals." Monthly Review: An

Independent Socialist Magazine 50, no. 7 (1998): 19-31.

."Theorizing the Politics of 'Islamic Feminism'." Feminist

Review 69 (winter 2001): 124-146. Mojab, Shahrzad, and Amir

Hassanpour. "Thoughts on the Struggle against 'Honor Killing'."

International Journal of Kurdish Studies 16, no. 1 (2002): 81-97.

Shahidian, Hammed. "Iranian Exiles and Sexual Politics: Issues of

Gender Relations and Identity." Journal of Refugee Studies 9, no.

1 (1996): 43-72, 113-116.

Shaikh, Sa'diyya. "Islam, Feminism and the Politics of

Representation." In The End of Liberation? Liberation in the

End! Feminist Theory, Feminist Theology and Their Political 
Implications, edited by Charlotte Methuen and Angela Berlis, 93-110. Lueven: Peeters, 2002.

Tohidi, Nayereh. "Women in Muslim societies: diversity within unity, Boulder,Co: Lynne Rienner publishers, 1998.

Tomac, Ayca "Debating Islamic Feminism: Between Turkish

Secular Feminist And North American Academic Critiques."

Queen's University. Kingston. Ontario. Canada. 2011.

Tuppurainen, Anne Johanna. "Challenges faced By Muslim women:

An evaluation of the writings of Leila Ahmed, ElIzabeth Fernea,

Fatima Mernissi and Amina Wadud." South Africa University. 2010.

Wadud-Muhsin, Amina. "Muslim Women as Minorities." Journal of Muslim Minority Affairs 10, no. 1 (1989): 161-170.

_. "On Belonging as a Muslim Woman." In My Soul is a Witness: African- American Women's Spirituality, edited by

Gloria Wade-Gayles, 253-265. Boston: Beacon Press, 1995. Wadud, Amina. "A'ishah's Legacy.” New Internationalist 345 (May 2002): 16-17. 